\title{
TECHNOLOGICAL DAMAGE TO CONCRETE AND OPERATION OF REINFORCED CONCRETE STRUCTURES
}

\author{
Dorofeyev V. S., Myronenko I. M., Pushkar N. V.
}

\section{INTRODUCTION}

When conducting surveys of the technical condition of reinforced concrete structures of port facilities, a large number of defects and damage are observed: hairline cracks along the longitudinal main reinforcement with a reinforcement corrosion layer thickness of up to $0.5 \mathrm{~mm}$; cracks along the longitudinal main reinforcement of up to $3 \mathrm{~mm}$ with traces of corrosion of reinforcement with a layer thickness of up to $3 \mathrm{~mm}$; inclined cracks in the index zone of the beams that intersect the main reinforcement, with an opening width of $0.4 \ldots 1.0 \mathrm{~mm}$; chipping of the protective layer along the longitudinal reinforcement due to corrosion; protrusion of compressed reinforcement of columns and main reinforcement of welded-wire fabric of pan constructions, etc. (Fig. 1) $)^{1}$.
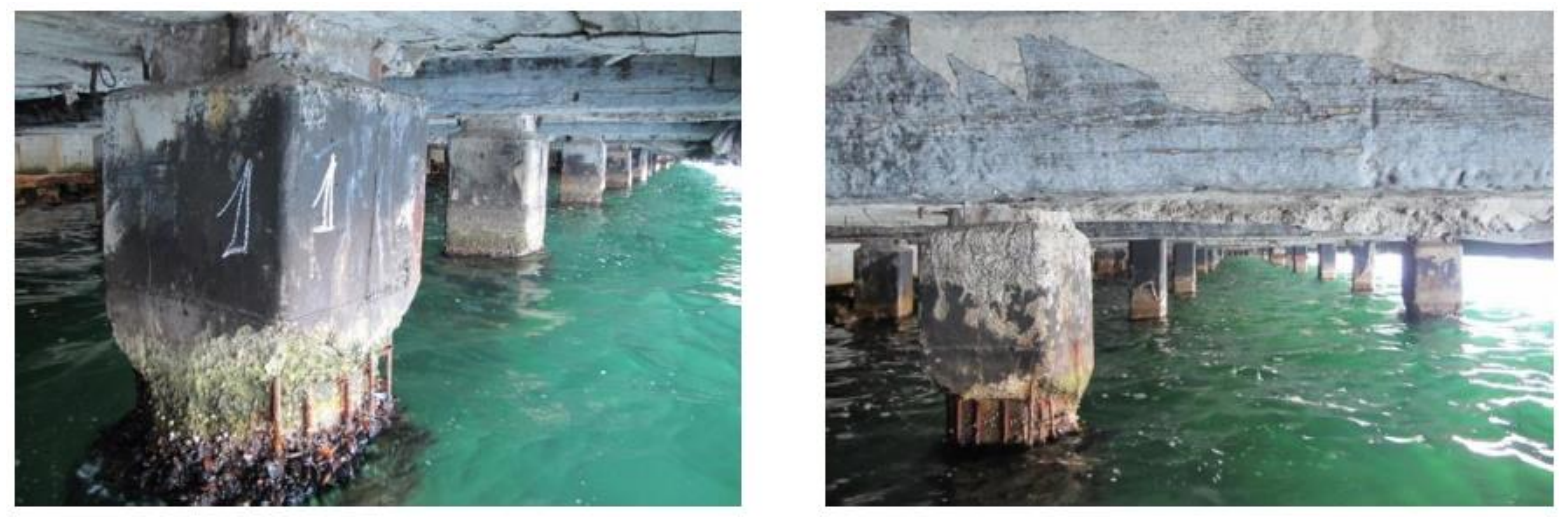

Fig. 1. Defects and damage to reinforced concrete structures

The cause of defects and damage is considered to be the heterogeneous structure of concrete, which is affected by an aggressive operating environment.

The aim of the work is to study the main causes of the emergence and development of defects in reinforced concrete structures during structure formation, the emergence and development of technological damage to

${ }^{1}$ Solomatov V. I., Vyrovoy V. N., Dorofeyev V. S. and Syrenko A. V. (1991). Kompozicionnye stroitel'nye materialy i konstrukcii ponizhennoj materialoemkosti [Composite building materials and structures of reduced material consumption]. Kiev: Budivelnyk, $144 \mathrm{p}$. 
concrete, the impact of initial damage on the operational properties of concrete and structures, as well as on the operation of reinforced concrete structures ${ }^{2,3,4}$.

\section{THE ORGANIZATION OF THE STRUCTURE OF COMPOSITE BUILDING MATERIALS}

It is advisable to consider the mechanism of crack nucleation in concrete on the basis of a system representative volume, which includes two adjacent $\mathrm{K}-\mathrm{N}$ clusters. This is due to the fact that the probability of the appearance of an internal (with respect to the system) interface is higher at the boundaries of interaction of structural blocks. The resulting tracking force of the particles on the surface of the clusters is directed towards the center of gravity of K-1 as a component of K-2. This increases the cohesive strength between the particles inside the clusters compared with the cohesive strength of the particles belonging to adjacent cluster formations.

The potential ability to form an incipient crack is laid in the disperse system at the very initial stages of its formation, and is determined by the composition and concentration of the dispersed phase, the surface interaction between the solid particles and dispersion medium, as well as between themselves. At a point in time $\tau_{i}$, the distribution of the ordinary particles between their "structural generators" and K-1 takes place over structural blocks. The particles acquire an angular moment; while for the particles of adjacent blocks the direction of movement does not coincide (Fig. 2).

This occurs at the interface of the contacting new aggregate structures. With a decrease in the concentration of the solid phase, an increase in the initial distance between the particles and the opening width of the interaggregate surface occurs due to the greater distance between the "structural generators". The path of each ordinary particle to the "structural generator" increases, which can lead to the appearance of heterogeneity and defects at the interface 5 .

2 Dorofeyev V. S., Vyrovoy V. N. (1998). Tehnologicheskaja povrezhdennost' stroitel'nyh materialov i konstrukcij [Technological damage of building materials and structures]. Odessa : Gorod Masterov, $168 \mathrm{p}$.

${ }^{3}$ Dorofeyev V. S., Pushkar N. V. (2011). Tehnologicheskaja povrezhdennost' i rabota zhelezobetonnyh izgibaemyh jelementov po naklonnym sechenijam [Technological damage and operation of reinforced concrete bending elements along inclined sections]. Odessa: Odessa State Academy of Building and Architecture, $161 \mathrm{p}$.

4 Dorofeyev V. S., Vyrovoy V. N. (1998). Tehnologicheskaja povrezhdennost' stroitel'nyh materialov i konstrukcij [Technological damage of building materials and structures]. Odessa : Gorod Masterov, p. 38.

5 Komohov P. P., Popov V. P. (1999). Jenergeticheskie i kineticheskie aspekty mehaniki razrushenija zhelezobetona [Energy and kinetic aspects of the mechanics of the reinforced concrete destruction]. Samara, $108 \mathrm{p}$. 


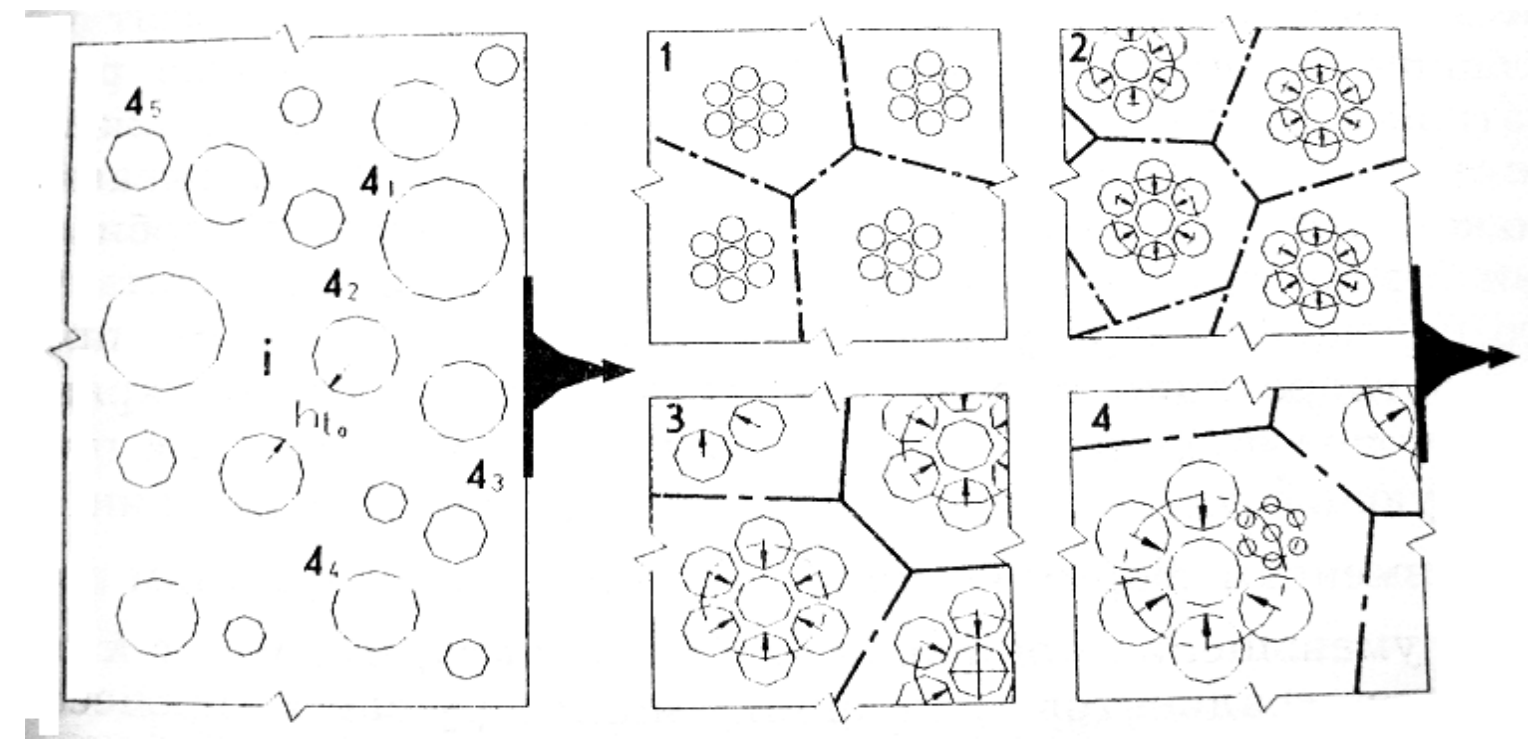

Fig. 2. The mechanism of formation of discrete structural blocks

$1 . . .4$ - typical structural levels; $4_{1} \ldots 4_{i}$ - dispersed particles; $h_{t 0}$ - mean distance between particles; $\longrightarrow$ - direction of movement of particles; $-\cdot \cdot \cdot-\cdot-\cdot \quad$ - interface between structural blocks

Therefore, the interface is a weak bond in the concrete structure, which, when applied to the structure of an external load, breaks in the first place.

Also the phenomenon that promotes the development of microdefects, i.e. the splitting effect of water, called the "Rehbinder effect" is known. Water, like any surface-active substance, penetrates the mouth of pores and microcracks and, thanks to the wedge-shaped structure of its molecule, which contains hydrogen ions, actively interacts at the tips of microdefects with the electron shells of the chemical elements that make up concrete or cement mortar. Such interaction creates a splitting tensile prestress in the mouths of pores and microcracks, which reduces the intensity of internal stress necessary for the further development of the microdefect and the amount of energy expended for this purpose ${ }^{6}$.

At the macro level, the interfaces between the matrix and aggregates form a kind of "shrinkage cells" inside the material structure. Their volume and shape depend on the ratio of cohesive and adhesive strength of the matrix, fractions of the aggregate, and its volumetric content in the mixture. The resulting "shrinkage cells" divide the macrostructure of the material into separate volume blocks interacting through their interfaces ${ }^{7}$.

6 Dorofeyev V. S., Vyrovoy V. N. (1998). Tehnologicheskaja povrezhdennost' stroitel'nyh materialov i konstrukcij [Technological damage of building materials and structures]. Odessa : Gorod Masterov, p. 49.

${ }^{7}$ Vyrovoy V. N., Dorofeyev V. S., Makarova S. S. and Abakumov S. A. (1991). Sposob vyjavlenija treshhin $\mathrm{v}$ betonnyh i zhelezobetonnyh konstrukcijah na neorganicheskom vjazhushhem [A method for detecting cracks in concrete and reinforced concrete structures on an inorganic binder]. Pos. dec. № 5008907/33 (059304) from 07/03/91. 
The organization of interfaces and the formation of shrinkage cells in concrete can occur in one of three ways:

1 - aggregates and the solution part react with the formation of a transition layer with other properties. In this case, the adhesion of the matrix material to the aggregate is higher than its cohesive strength. Volumetric shrinkage deformations are redistributed in the solution part with the formation of interfaces in the matrix material (Fig. 3, a).

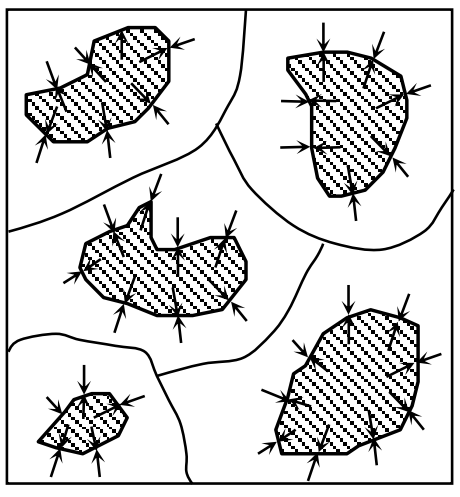

a

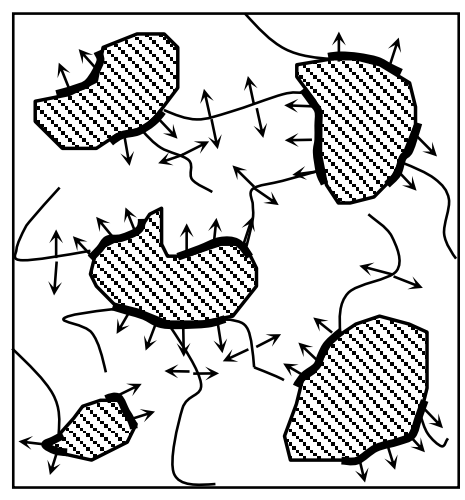

b

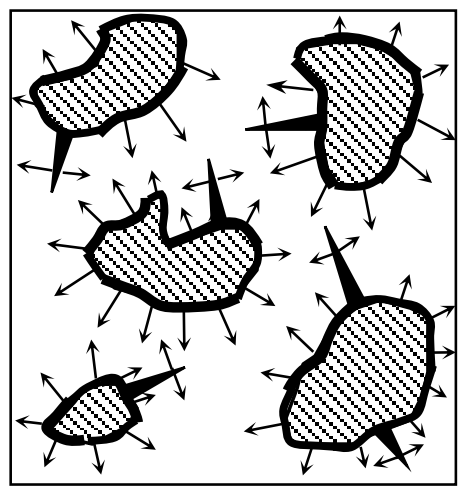

c

Fig. 3. Distribution of shrinkage deformation and the nature of the macrostructure cracking

2 - aggregates and the mortar part are mutually dissolved, and the dissolution products form a zone of the modified material. In this case, the adhesive and cohesive strengths are equal. The distribution of shrinkage deformation occurs both in the matrix material and along the boundaries of the aggregates (Fig. 3, b).

3 - the solution part does not react with aggregates, and they do not mutually dissolve. The adhesion of the matrix to the surface of the aggregate is lower than its cohesive strength. The interfaces pass along the boundaries of the aggregates, shrinkage deformations are directed from the aggregates (Fig. 3, c).

Due to the polyminerality of cements and aggregates in concrete, the presence of all three types of interfaces is possible.

Volumetric shrinkage deformations inside structural blocks resulting from hardening of concrete cause deformations and tensile stresses on interfaces. This can cause a disruption in the continuity of the matrix and lead to the appearance of an incipient crack.

In the process of the structure formation of systems, the following stages of crack growth are distinguished:

1 - accumulation of plastic deformations in the zone of interparticle contacts due to intrinsic volumetric deformations of the hardening system. 
Irreversible deformation of the crack banks occurs due to deformations of different significance and direction;

2 - destruction of the contact zone and an increase in the length of cracks by a value equal to the distance between the interparticle contacts. The area of the crack increases with an increasing area of its banks;

3 - the typical accumulation of plastic deformations with their redistribution on the new crack banks.

The movement of cracks at the level of structure inhomogeneities is a kind of leap from one interparticle bond to another, while a moving crack goes around structural blocks that are disadvantageous for itself and tends to develop along energetically efficient trajectories. Therefore, the microtrajectories of the cracks formed during the structure formation of the material are sinuous, with an individual morphology of each bank. Due to the formation of structural blocks of different scale levels, the nucleation and growth of cracks in the material does not occur simultaneously throughout the volume. The growth of each crack changes the micro-deformed state of the system individual volumes, which can accelerate or decelerate the growth of adjacent cracks; therefore, as a rule, cracks are present in the material, different in length, shape and opening width.

It is established that the mechanism for the development of technological cracks at the macro level is determined by the value and gradient of shrinkage deformations on the crack banks. In real materials, the coincidence of the symmetry axes of the crack and the medium in which it develops is a special case. More often, there is a situation in which different shrinkage deformations occur on the banks. In this case, the zone of critical plastic deformation is shifted toward the side of the crack, which undergoes large shrinkage deformations. This causes a change in the direction of the crack movement, and its rotation is carried out until the shrinkage deformation on the opposite crack banks is not aligned.

At the macro level, a continuous crack growth occurs, which depends on the value and kinetics of volumetric deformations of the material microstructure and on the cases of the formation of adhesive and cohesive bonding forces between the matrix and inclusions, which determine the mechanism of the formation and distribution of shrinkage deformations in the system.

Let us consider a model of a concrete structural cell with a distance between aggregates of $h=0,1 r$. With a constant internal interface, volumetric deformations are redistributed in the matrix material so that circumferential compressive deformations appear at the interface and become radial tensile in the peripheral zones of the matrix (Fig. 4).

Thus, the formation of internal interfaces between the matrix material and inclusions is determined by the nature of the adhesive-cohesive bonding forces 
at the interfaces, stacking methods, and the number of inclusions. A deliberate change in these parameters will make it possible to predict damage to the macrostructure of composite building materials due to hereditary defects.
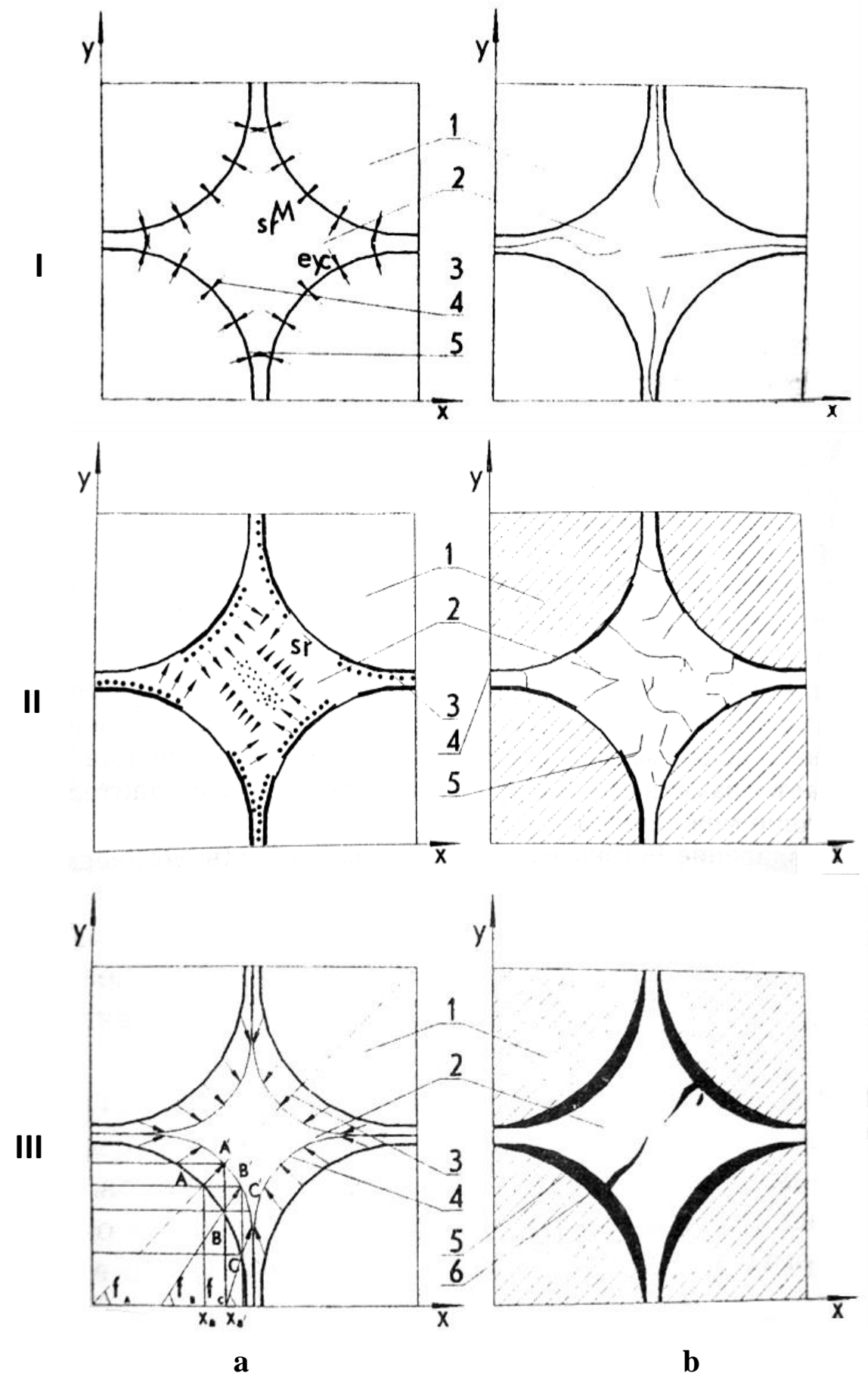

Fig. 4. The mechanism of distribution of deformations (a) and the nature of the crack formation of the macrostructure (b) during cubic shrinkage of aggregates for cases:

$$
\text { I }-R_{A}>R_{K} ; \text { II }-R_{A}=R_{K} ; \text { III }-R_{A}<R_{K} \text { : }
$$

1 - aggregates; 2 - matrix; 3 - stresses and cracks in the matrix;

4, 5 - new interface and adhesion cracks; 6 - crack in matrix material 


\section{THE TRANSFORMATION MECHANISM OF TECHNOLOGICAL CRACKS INTO OPERATIONAL ONES}

Let us consider the methods for quantitative estimate of the technological damage to building composites and structures. In the general case, several typical types of damage can be distinguished, which differ in the mechanisms of formation:

- damage to individual components, which is introduced with them into the material and structure;

- damage that occurs during the period of technological processing of the initial components into the material and into the structure;

- damage that occurs when the structural material is exposed to operational loads and influences (Fig. 5).

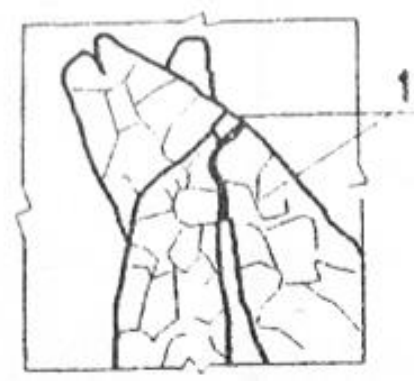

a

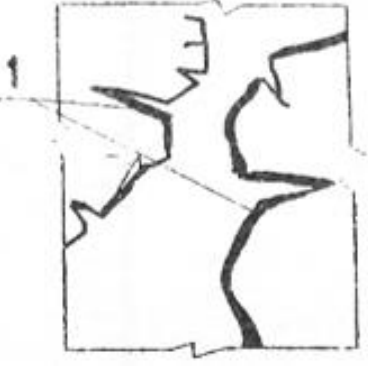

b

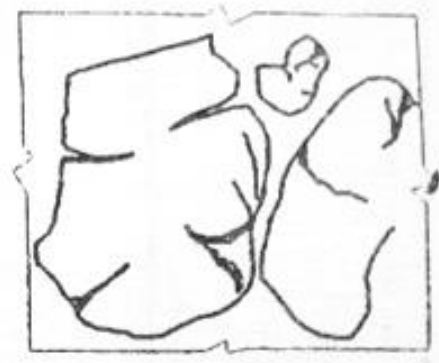

c

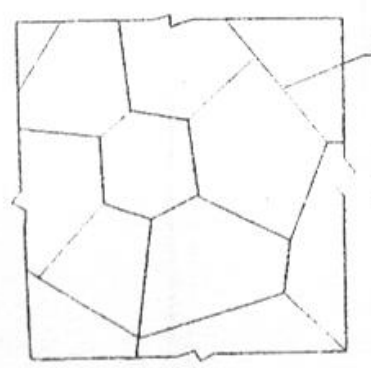

d

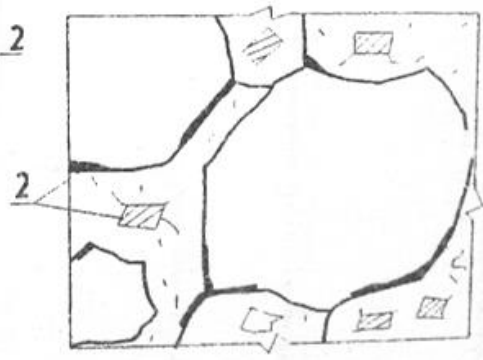

e

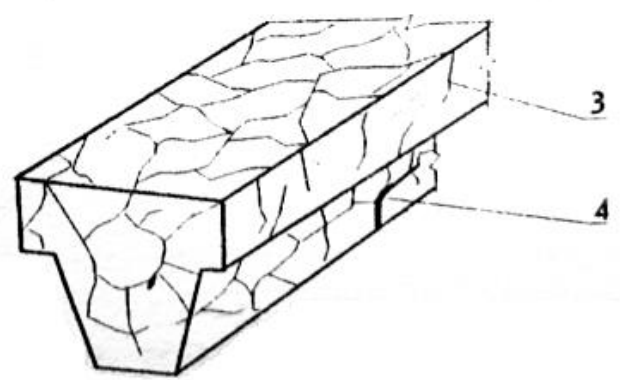

f

Fig. 5. The nature of the damage to crystals (a), cement grains (b), fine aggregates (c), cement stone (d), concrete (e) and structure (f):

1 - cracks in the initial components; 2 - cracks formed during the structure formation of materials; 3 - cracks formed due to the structure geometric features;

$$
4 \text { - operational cracks }
$$


The object of the analysis is the defects that occur during the technological processing of building materials and structures. Such defects are referred to initial, technological or hereditary defects. Such defects include pores, capillaries, cracks of various types, etc. that are present in the structure before the application of operational loads. A quantitative estimate of concrete damage by technological defects was carried out through the determination of damage by surface cracks.

Damage to concrete by defects was determined by measuring the length of surface cracks with a curvimeter with an accuracy of $0.001 \mathrm{~mm}$ on opposite sides of the sample. Surface cracks were fixed by exposure of samples in aqueous solutions of tannin. Changes in the alkalinity of concrete in the region of cracks changed the color of tannins, detecting and fixing cracks ${ }^{8}$. The adopted method for determining cracks has shown that it can detect cracks with an opening width of $2 \mu \mathrm{m}$ or more and a length of $2 \mathrm{~mm}$ or more. Technological cracks were determined on samples 200 days aged (Fig. 6).

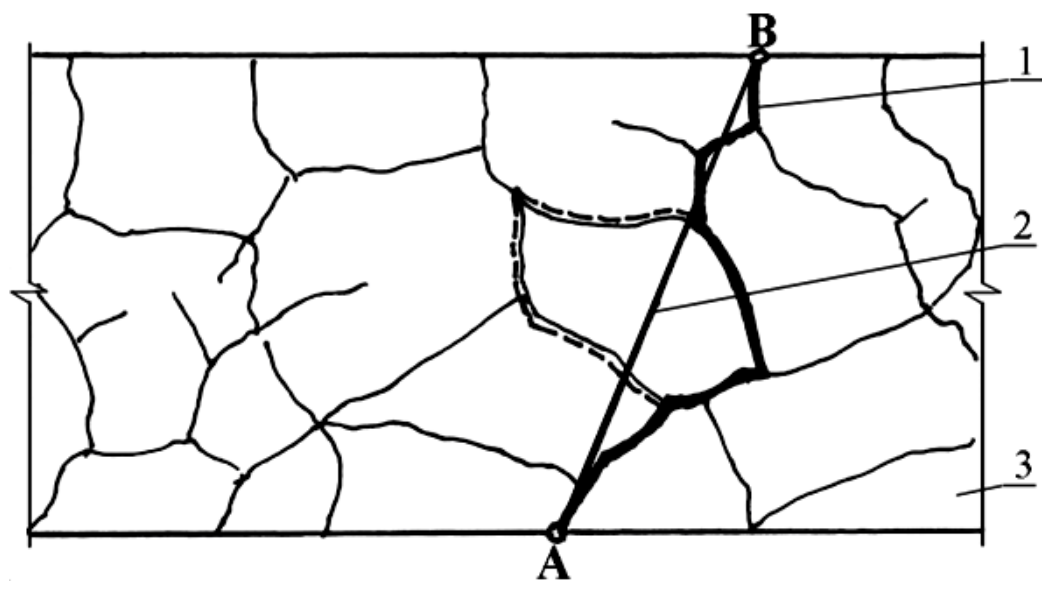

Fig. 6. Method for determining the damage coefficient:

1 - technological crack length $l_{c r c} ; 2$ - geodetic line $l$;

3 - dedicated area on the concrete surface

$$
\mathrm{C}_{\mathrm{d}}=1_{\mathrm{crc}} \mathrm{l}
$$

The physical meaning of the coefficient is to estimate the specific length of surface cracks developed per unit of length. With an increase in $C_{d}$, the strength and deformation characteristics of concrete decrease.

The depth of technological cracks, as well as cracks that occur during operation and loading, was determined using an ultrasonic device UK14P. The crack depth measurement scheme is shown in Fig. 7.

8 Dorofeyev V. S., Vyrovoy V. N. (1998). Tehnologicheskaja povrezhdennost' stroitel'nyh materialov i konstrukcij [Technological damage of building materials and structures]. Odessa : Gorod Masterov, p. 88. 


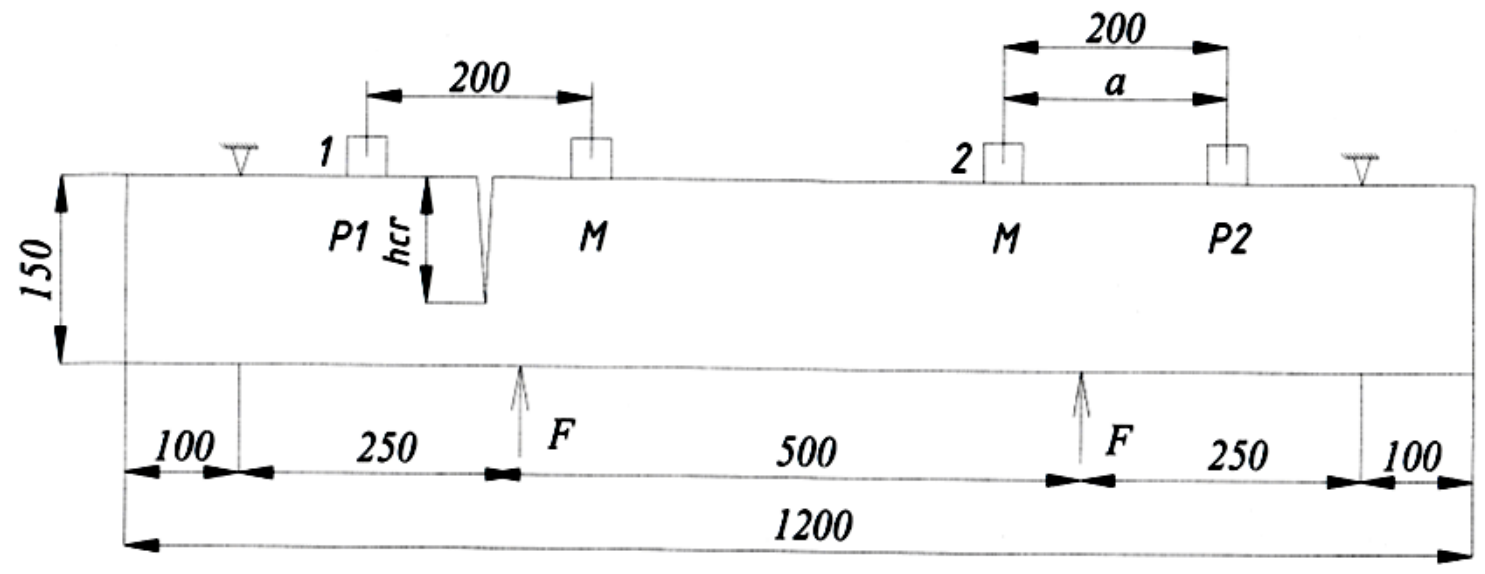

Fig. 7. Crack depth measurement scheme:

1 - measurement base on concrete through a crack (position of I-P1 sensors); a - measurement base on intact concrete (position of I-P2 sensors)

The device automatically calculates the crack depth using the formula:

$$
h_{m}=\frac{a}{2} \cdot \sqrt{\left(\frac{t_{1}}{t_{a}}\right)^{2}-1} .
$$

When studying reinforced concrete beams on the effect of low-cycle load, the dependence of the crack depth on load was established (Fig. 8).

It was established that technological cracks in reinforced concrete beams had an opening width of $0.005 \ldots 0.3 \mathrm{~mm}$ at a depth of $5.0 \ldots 8.0 \mathrm{~mm}$, while the maximum crack width and depth were observed in the area of the main reinforcement, which can be explained by the influence of shrinkage deformations.

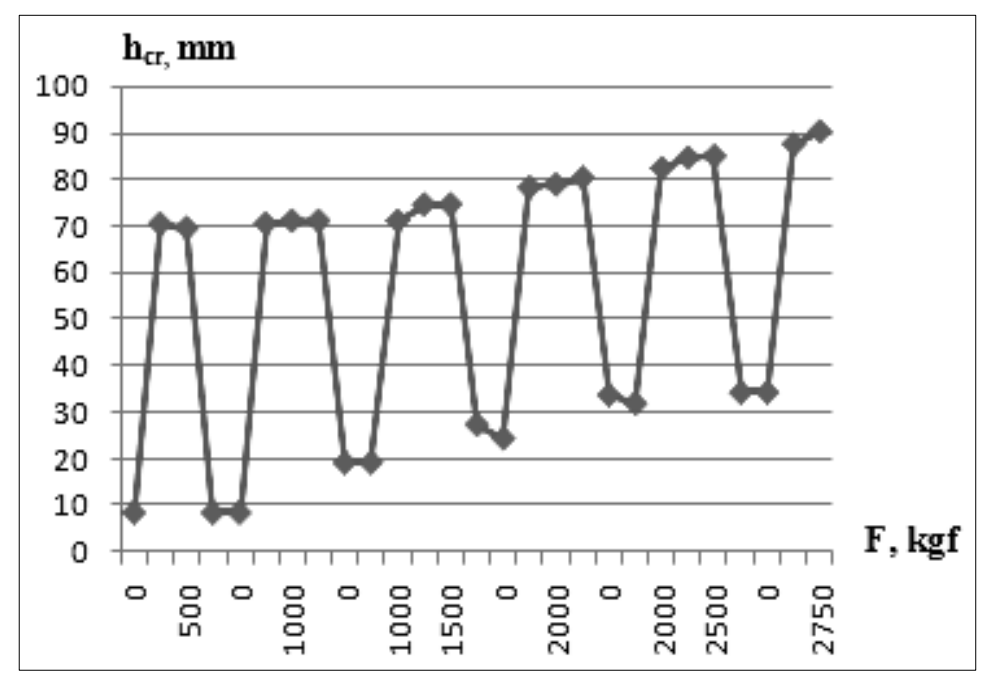

Fig. 8. Graph of dependence of the crack depth on load 
Let us consider the mechanism of transformation of technological cracks into operational ones. To explain the mechanism of crack nucleation under the action of alternating loads, several models are proposed (Fig. 9).

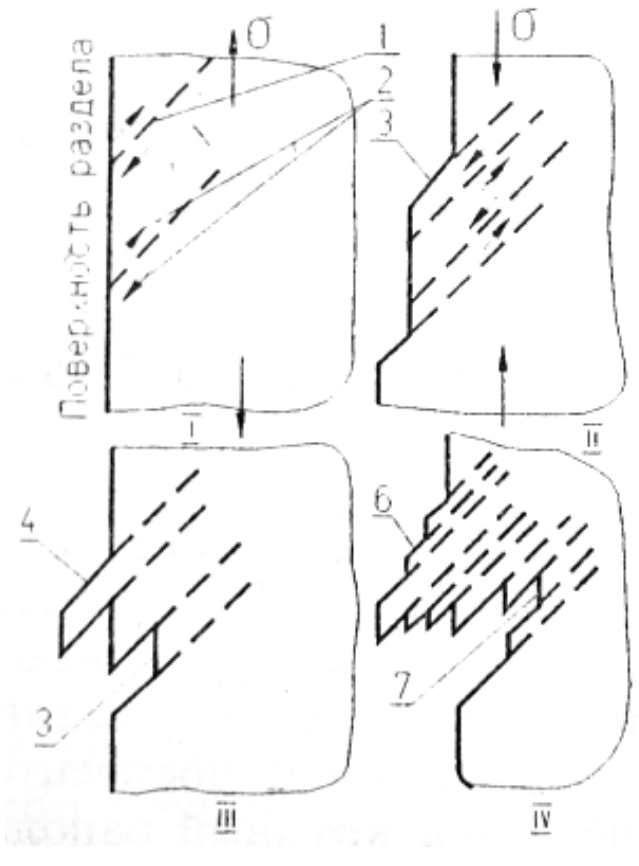

a

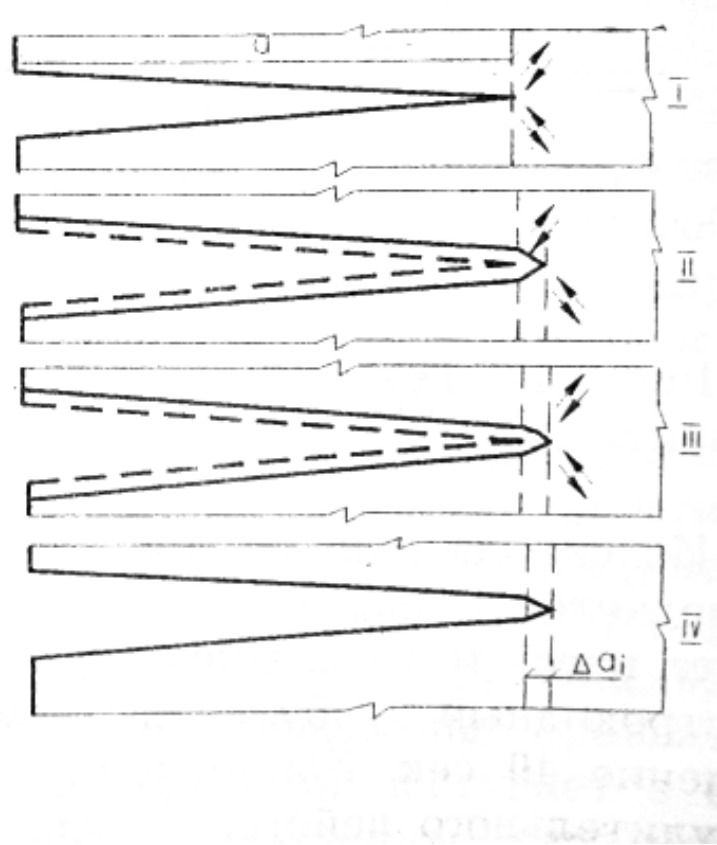

b

Fig. 9. The mechanism of crack nucleation (a) and their development (b):

I...IV - stages of nucleation and development of fatigue cracks; $1 . . .3$ - plane deformation; 4, 5 - surface nature change; 6 - extrusion crack nucleation;

\section{7 - intrusion crack nucleation}

Under the action of tensile stresses in a plane, a shift occurs. The shift in the opposite direction (changing the sign of stresses) is parallel to the plane. In this case, extrusion or intrusion of a surface of sufficiently isotropic and elastic material is possible. At alternating stresses, the intrusion is an incipient crack capable of growing until it reaches the length at which stresses at its tip become the determining condition for further growth (Fig. 9, b).

It is assumed that a shift occurs in the field of high stresses at the crack tip. This causes an increase in the crack opening width and its growth by $\Delta a$. A shift occurs in another plane (stage III). Diffusion processes can turn the sharp end of a crack into a blunt one. Under the action of compressive stresses, the crack opening width decreases, and the resulting plastic deformations contribute to the restoration of the sharp mouth (stage IV). After that, the cycle repeats and the crack increases by the next value of $\Delta a_{i}$.

Imagine a semi-infinite plate with a crack located along the axis of symmetry (Fig.10). Under the influence of external influences, the material undergoes volumetric deformations with a variable sign. 


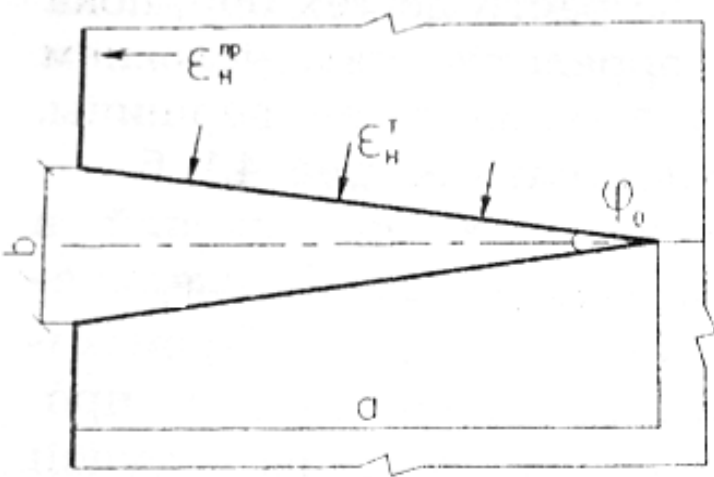

a

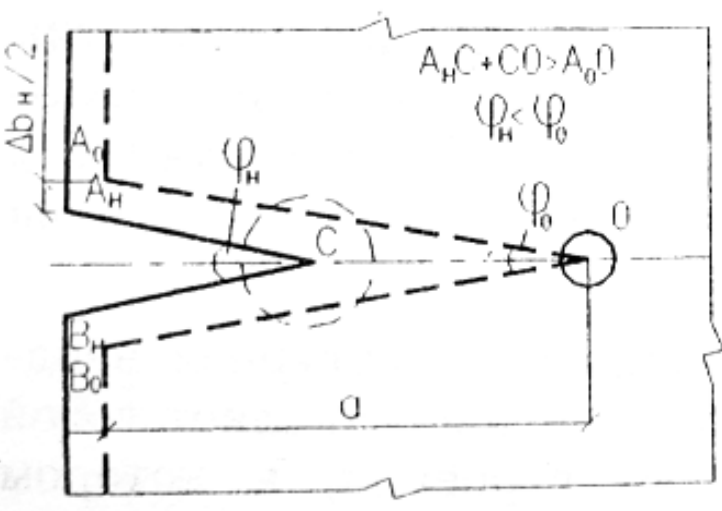

c

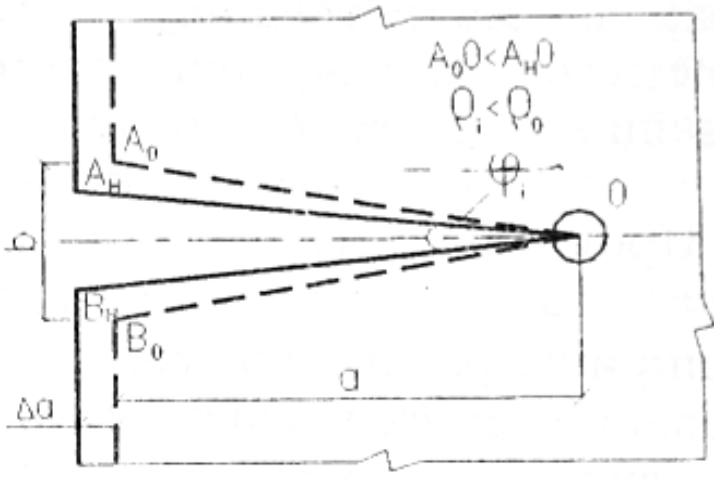

$\mathbf{b}$

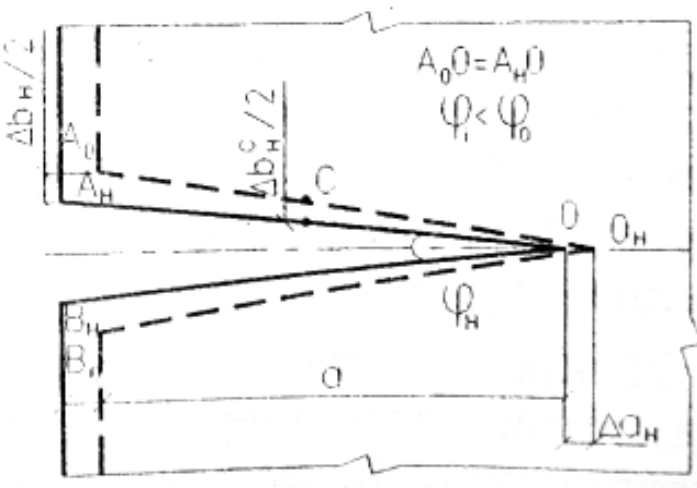

d

Fig. 10. The mechanism of fatigue growth of a technological crack with alternating volumetric swelling deformations: geometric parameters of the technological crack (a); change in the geometrical parameters of the crack during plastic deformations at its mouth (b); change in crack parameters during plastic deformation of the mouth and its banks (c); change in crack parameters due to its growth (d).

The cycle begins with deformations of increasing volume. By virtue of the assumptions made, the crack banks will move parallel to themselves ${ }^{9}$.

Let us introduce the final dimensions of the sample and assume that the cracks in it are parallel to each other at a distance at which an uneven distribution of deformations occurs both along the length of the crack and on the opposite banks (Fig. 11).

An increase in the volume of the material causes an uneven distribution of deformations along the crack banks (Fig. 10, b).

The deformation distribution in the region of the $A B$ crack under the condition of a linear relationship between the volumetric changes in the material and its linear deformations was determined by the graphic-analytical method.

9 Dorofeyev V. S., Zinchenko H. V. (2017). Chisel'ni doslidzhennja, shho harakterizujut' pochatkovu stadiju roboti kompozitiv [Numerical studies characterizing the initial stage of composites]. New technologies in construction. Kiev, Issue 33, p. 35. 


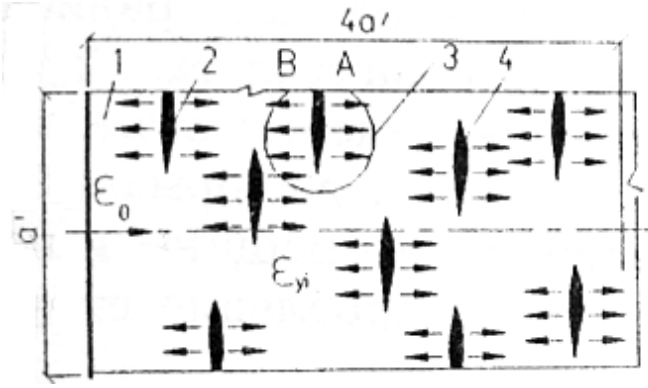

a

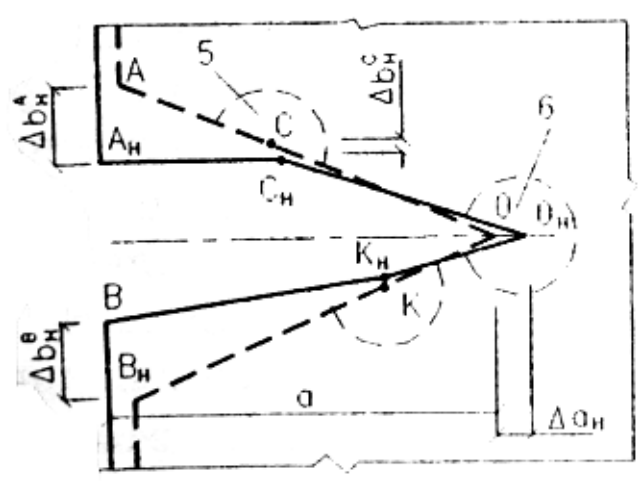

c

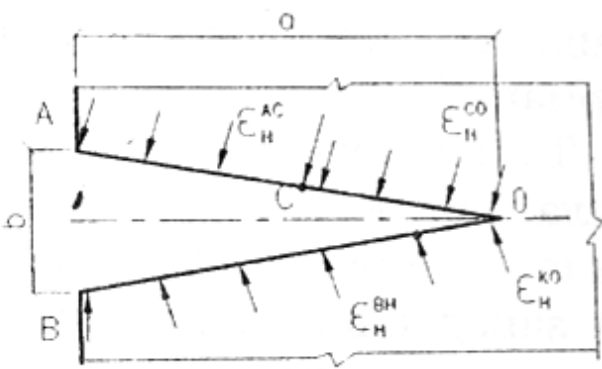

b

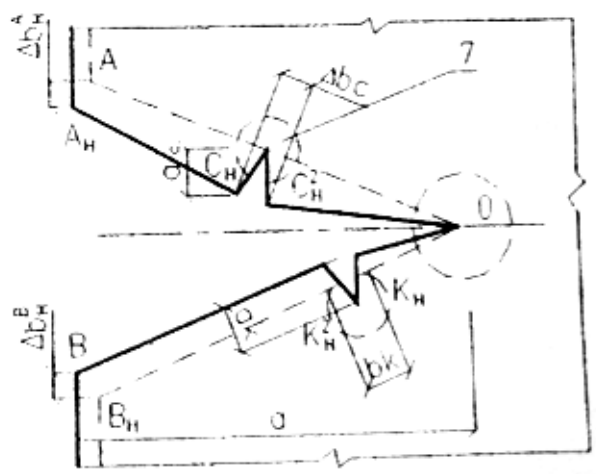

d

Fig. 11. The mechanism of growth of a fatigue crack under the action of various shrinkage deformations on its banks: the distribution of shrinkage deformations in a cracked sample (a); geometrical parameters of the crack and the distribution of swelling deformation on its banks (b); change in the geometrical parameters of the crack due to plastic deformation of the banks and mouth (c); the same due to the nucleation of new cracks on its banks (d); 1 - sample; 2 - surface cracks; 3 - differentsized shrinkage deformations; 4 - cracks in the volume of material; 5 - plasticity zones on the banks; 6 - plasticity zones at the mouth; 7 - new interfaces on crack banks

The analysis showed that, due to the geometric features of the relative position of the cracks and their sizes, deformation gradients arise, which cause the appearance of shear deformations. The latter can occur both on the very bank of the crack and at its mouth. On the bank of the crack, deformations are able to form extrusion sections, which leads to the formation of fatigue incipient cracks. The shift at the crack tip leads to its development by the value of $\Delta a$. The deformation gradient also determines the direction of development of such a crack. Thus, even at the stage of increasing the volume of the material with uneven distribution of swelling deformations on the crack banks, crack growth and the appearance of incipient cracks are possible. The material structure is crushed according to the scheme (Fig. 11, c).

The potential possibility of growth and transformation of technological cracks into operational ones with alternating volume changes in the material sets the task of studying the effect of the number of cycles of volume changes on the damage accumulation in concrete. The increase and decrease in the volume of material occurs during its operation under conditions of periodic wetting or drying, temperature changes, etc. 
The samples 540 days aged were tested for the effects of low-cycle wetting and drying in order to determine the nature of technological damage and its effect on the kinetics of development of operational cracks. The number of wetting and drying cycles was 80 and 110. During the study, the damage accumulation and $C_{d}$ were measured. The studies have shown that with the increase in the wetting and drying cycles in concrete of various compositions, damage accumulates ${ }^{10,11,12}$. In this case, three cases of damage accumulation can be distinguished (Fig. 12).

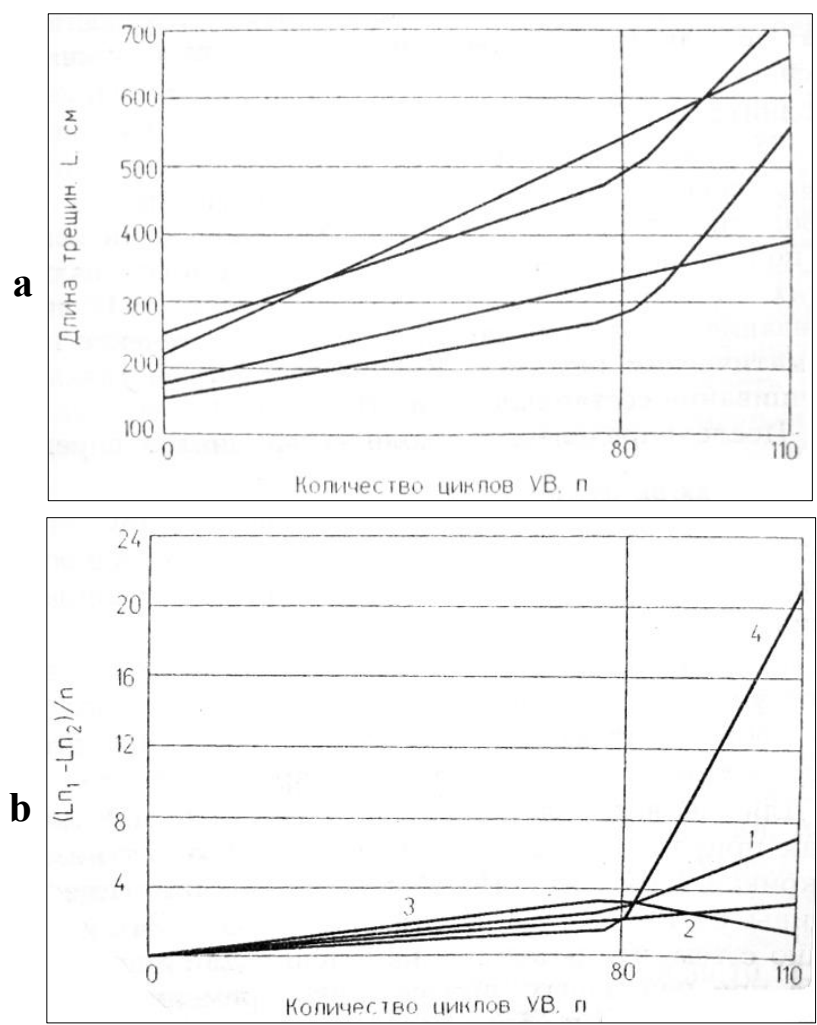

Fig. 12. The effect of wetting and drying on the growth of surface cracks: change in the length of surface cracks (a); change in the crack growth rate (b); $1 . . .4$ - concrete composition numbers

10 Dorofeyev V. S., Pushkar N. V. (2018). Deformacii betona zhelezobetonnyh konstrukcij gidrotehnicheskih sooruzhenij pri ciklicheskih vozdejstvijah. [The deformations of concrete of reinforced concrete constructions of hydrotechnical structures under cyclic exposure]. New technologies in construction. Kiev, Issue 3, pp. 35.

${ }^{11}$ Dorofeyev V. S., Pushkar N. V. and Brednev A. M. (2019). Deformacii betona na beregah tehnologicheskih treshhin pri znakoperemennom vozdejstvii sredy jekspluatacii konstrukcij [Concrete deformations on the banks of technological cracks at sign-alternating impact of the structure operation environment]. Current scientific research in the modern world. Pereyaslov-Khmelnicki, vol. 1(45) 4, 2, pp. 88.

${ }^{12}$ Dorofeyev V. S., Pushkar N. V. and Zinchenko H. V. (2020). Obrazovanie i razvitie silovyh treshhin $\mathrm{v}$ zhelezobetonnyh izgibaemyh jelementah [Formation and development of force cracks in reinforced concrete bending elements]. Proceedings of the 7th International Conference on Perspectives of world science education. Osaka, pp. 280. 
For the first case (Fig. 12, a) it is typical that in the first 80 cycles, the crack length extension occurs insignificant. The maximum crack length extension is $64 \%$. This may be due to the fact that volumetric changes for these concrete structures during the initial cycles of alternating deformation cannot lead to the formation of new interfaces (cracks), and a change in the length of the cracks can be associated with the growth of technological cracks.

The second case is characterized by an intense change in the length of surface cracks, which can be $290 \%$. This may be due to the emergence and development of new interface surfaces. As the number of cycles increases from 80 to 110 , a sharp damage accumulation occurs, and the maximum increment is $399 \%$.

Compositions for which the change in damage occurs in proportion to the number of cycles can be referred to a separate group.

The difference in the change in the damage to concrete allows us to estimate the rate of accumulation of defects according to their intensity (Fig.12, b). The data show that for some concrete compositions, the maximum rate of defect accumulation occurs at 80 cycles. A further increase in the number of cycles reduces the intensity of the length crack extension. For other concrete compositions (4), the intensity of accumulation of defects increases sharply after 80 cycles.

The operation of the structure in zones of alternating exposure to humidity suggests that when changing climatic conditions (for example, in the winter period) they can repeatedly freeze and thaw.

The test was carried out on samples with dimensions of $70 \times 70 \times 280 \mathrm{~mm}$ according to the accelerated method (saturation and thawing of the samples was carried out in a $5 \% \mathrm{NaCl}$ solution, and freezing in the chamber at $50{ }^{\circ} \mathrm{C}$ ). Thawing was carried out in a bath with water, the temperature of which was $15 \ldots 20^{\circ} \mathrm{C} .100$ cycles of freezing and thawing were carried out.

The experiments showed that as the number of cycles in concrete increases, the damage accumulates. Two cases of the damage accumulation can be distinguished (Fig. 13).

The first case is characterized by a slight increase in the crack length extension. The maximum crack length extension is $60 \%$. This may be due to the gradual growth of technological cracks.

The second case is characterized by a noticeable change in the length of surface cracks, which is $211 \%$. This is due to the appearance and development of new interfaces and new cracks.

Similar data were obtained for the damage coefficient. 


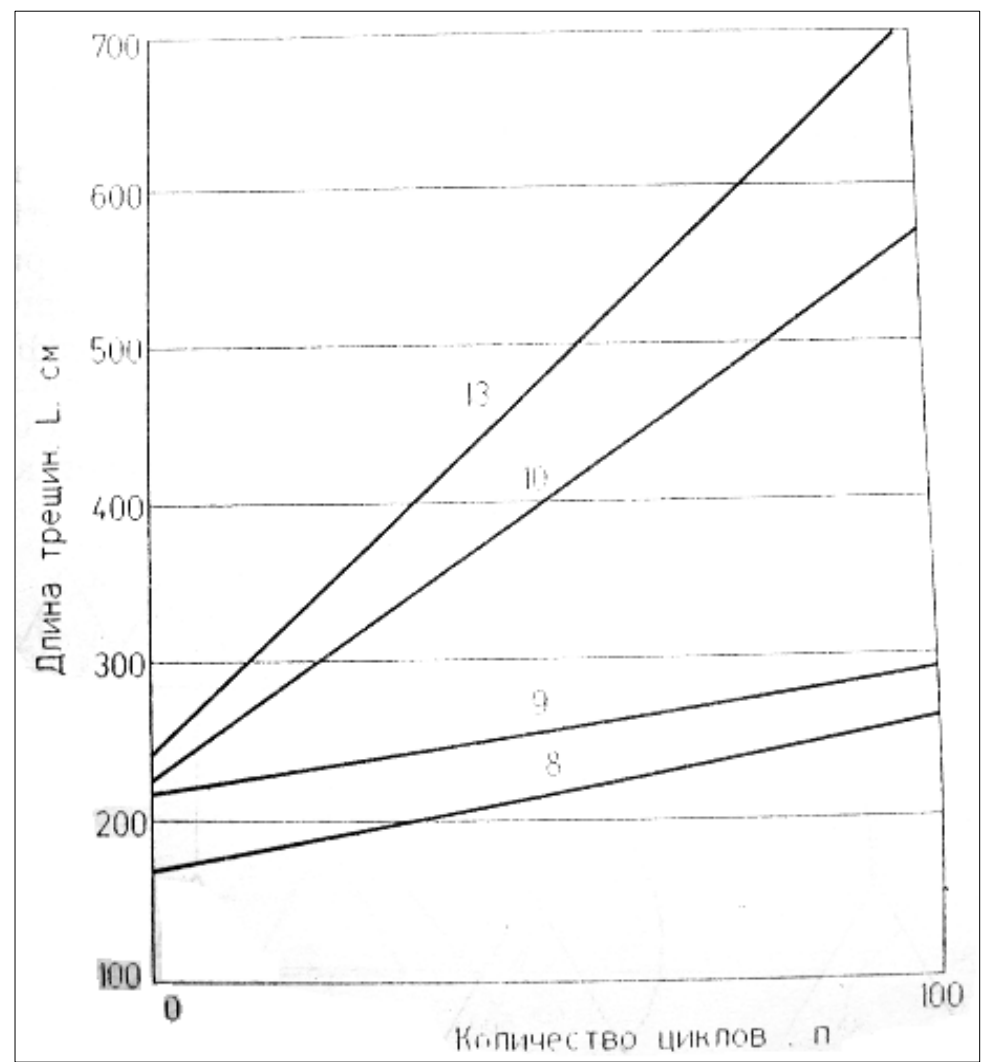

Fig. 13. The effect of the number of freezing and thawing cycles on the change in the length of surface cracks: $8 . . .13$ - concrete composition numbers.

The work is devoted to the study of the work of reinforced concrete structures taking into account technological damage ${ }^{13,14,15,16}$ - mathematical

13 Dorofeyev V. S., Zinchenko H. V. (2017). Asimptoticheskij analiz naprjazhennodeformirovannogo sostojanija i polja sploshnosti u vershiny treshhiny normal'nogo otryva zhelezobetonnyh izgibaemyh jelementah [Asymptotic analysis of the stress-strain state and continuity field at the crack tip of the normal separation of reinforced concrete bending elements]. Current scientific research in the modern world. Pereyaslov-Khmelnicki, Issue 12 (32), part 1, p. 84.

${ }^{14}$ Dorofeyev V. S., Zinchenko H. V. and Romaniuk V. V. (2017). Doslidzhennja kharakteru rozpodilu naprughy ta peremishhenj bilja vershyny trishhyny $\mathrm{v}$ zalizobetonnykh elementakh [Investigation of the nature of stress distribution and displacements near the crack tip in reinforced concrete elements]. Resource intensive materials, structures, buildings and constructions. Rivne, Issue 34, p. 129.

${ }^{15}$ Zinchenko H. V., Dorofeev V. S. (2019). Stressed-deformed condimion and distruction of technologically damaged reinforced concrete structures. Publishing house "Baltija Publishing”. Monografia: Riga, Latvia, pp. 165. doi.org/10.30525/978-9934-588-15-0-56.

16 Dorofeyev V. S., Zinchenko H. V. and Tselikova A. G. (2017). Vplyv tekhnologhichnoji poshkodzhenosti materialu na napruzheno-deformovanyj stan zghynaljnykh zalizobetonnykh elementiv [Influence of technological damage of material on the stress-strain state of bending reinforced concrete elements]. Bulletin of Lviv National Agrarian University, Architecture and agricultural construction. Lviv, Issue 18, p. 75. 
methods for investigating the stress-strain state at the crack tip; ${ }^{17,18,19,20,21,22}$ the effect of technological damage on the operation of structures.

\section{CONCLUSIONS}

1. Initial (technological) cracks that arise and develop during the period of technological processing of the material, prior to application of operational loads to the structure, determine the total structure damage by technological defects. The number and type of technological cracks affects the physical and mechanical characteristics of the material and to a large extent determines the nature of the distribution of deformations and stresses between the individual structural blocks of the structure material, the kinetics of the accumulation and development of operational cracks, the nature of the structure destruction and its bearing capacity.

2. The formation of the internal interfaces between the matrix material and the inclusions is determined by the nature of the adhesive-cohesive bonding forces at the interfaces, stacking methods and the number of inclusions. A deliberate change in these parameters will make it possible to predict damage to the macrostructure by technological defects.

${ }^{17}$ Dorofeyev V. S., Pushkar N. V. (2018). Vlijanie struktury gidrotehnicheskih betonov na razrushenie pri udarnyh vozdejstvijah [The influence of the concrete structure on the destruction under impact]. Current scientific research in the modern world. PereyaslovKhmelnicki, Issue 2 (34), part 6, p. 35.

${ }^{18}$ Dorofeyev V. S., Pushkar N. V. (2018). Rujnuvannja ghidrotekhnichnykh betoniv pry diji cyklichnykh navantazhenj i vplyviv [Destruction of hydraulic concrete under the action of cyclic loads and influences]. Proceedings of the International Multidisciplinary Conference "Science and technology of the present time: Priority development directions of Ukraine and Poland". Wolomin, Republic of Poland, p. 94.

19 Dorofeyev V. S., Litvinenko V. V., Pushkar N. V. (2019). Tehnologicheskaja povrezhdennost' i ejo vlijanie na prochnost' kontakta starogo i novogo betonov [Technological damage and its influence on the contact strength of old and new concrete]. Current scientific research in the modern world. Pereyaslov-Khmelnicki, Issue 4(48), part 1, p. 83.

20 Dorofeyev V. S., Litvinenko V. V., Pushkar N. V. (2020). Prochnostnye i deformativnye harakteristiki gidrotehnicheskih betonov sborno-monolitnyh konstrukcij [Strength and deformation characteristics of concretes of composite structures]. Scientific achievements of Modern Society. Liverpool, p. 442.

${ }^{21}$ Dorofeyev V. S., Pushkar N. V. (2020). Svjaz' tehnologicheskoj povrezhdennosti betona s prochnost'ju rekonstruiruemyh portovyh sooruzhenij [Relation of technological damage to concrete with the strength of reconstructed port facilities]. Current scientific research in the modern world. Pereyaslov-Khmelnicki, Issue 2 (58), part 1, p. 75.

${ }^{22}$ Yehupov V. K. (1965) Raschet zdaniy na prochnost', ustoychivost' i kolebaniya [Calculation of buildings for strength, stability and fluctuations]. "Budivelnik", Kyiv (in Russian) 
3. The accepted methodology for estimating technological damage through surface cracks showed that the proposed method can detect cracks with an opening width of $5 \mu \mathrm{m}$ and a length of more than $2 \mathrm{~mm}$, which makes it possible to study the development of technological cracks under the action of traces of operation, and the transformation of technological cracks into operational ones.

4. The influence of initial damage of materials on the operational properties of composite building materials and structures is established. The analysis allows us to conclude that an increase in the initial damage due to the formation of many cracks contributes to the intensive damage accumulation both due to technological cracks and due to the formation of new interfaces (cracks). This affects the nature of the destruction of the samples after alternating deformation, and allows us to determine the resistance of the material during their alternate wetting and drying, freezing and thawing.

5. The technological damage to the microstructure of materials determines the conditions for the development of fatigue cracks in it and its resistance to low-cycle loads. The directional structure formation with the help of aggregates of the optimal type, quantity and dispersion allows minimizing the number of hereditary defects. Thus, the initial organization of the microstructure with a minimum number of dangerous defects is responsible for the subsequent reliability of the operation of building structures.

\section{SUMMARY}

Composite building materials (concrete), the properties of which are formed and transformed in time on the internal surfaces, are considered. A mechanism is described for the formation of the structure of composite building materials, i.e. concrete with the formation of interfaces on the contact plane, inclusions and matrix. Fine and coarse aggregates are considered as inclusions, and mortar fraction and cement mortar as a matrix. Such a selection of structural levels makes it possible to establish the occurrence of dangerous defects, which are larger than the size of the elements constituting the structure. Therefore, the size of the defect, safe at one structural level, becomes dangerous at a lower level. Technological cracks determine structural damage by technological defects, which are transformed into operational ones, and determine operational reliability. It is proposed to determine the heterogeneity of the structure through surface damage by technological defects.

The nature of the crack formation and the development of cracks under the action of an external load in flexible concrete elements depending on the technological damage has been established. It is shown that the distribution of shrinkage deformations in concrete with a network of technological cracks affects the deformability and resistance at the weather impact, as well as under conditions of low-cycle fatigue loading. 


\section{REFERENCES}

1. Dorofeyev V. S., Pushkar N. V. (2018). Stojkost' betona gidrotehnicheskih sooruzhenij pri mnogokratnom uvlazhnenii i vysushivanii [Resistance of concrete of port structures with repeated wetting and drying]. Current scientific research in the modern world. Pereyaslov-Khmelnicki, Issue 4 (36), part 10, pp. 68-73.

2. Solomatov V. I., Vyrovoy V. N., Dorofeyev V. S. and Syrenko A. V. (1991). Kompozicionnye stroitel'nye materialy i konstrukcii ponizhennoj materialoemkosti [Composite building materials and structures of reduced material consumption]. Kiev: Budivelnyk, $144 \mathrm{p}$.

3. Dorofeyev V. S., Vyrovoy V. N. (1998). Tehnologicheskaja povrezhdennost' stroitel'nyh materialov i konstrukcij [Technological damage of building materials and structures]. Odessa: Gorod Masterov, $168 \mathrm{p}$.

4. Dorofeyev V. S., Pushkar N. V. (2011). Tehnologicheskaja povrezhdennost' i rabota zhelezobetonnyh izgibaemyh jelementov po naklonnym sechenijam [Technological damage and operation of reinforced concrete bending elements along inclined sections]. Odessa: Odessa State Academy of Building and Architecture, $161 \mathrm{p}$.

5. Komohov P. P., Popov V. P. (1999). Jenergeticheskie i kineticheskie aspekty mehaniki razrushenija zhelezobetona [Energy and kinetic aspects of the mechanics of the reinforced concrete destruction]. Samara, $108 \mathrm{p}$.

6. Vyrovoy V. N., Dorofeyev V. S., Makarova S. S. and Abakumov S. A. (1991). Sposob vyjavlenija treshhin $\mathrm{v}$ betonnyh i zhelezobetonnyh konstrukcijah na neorganicheskom vjazhushhem [A method for detecting cracks in concrete and reinforced concrete structures on an inorganic binder]. Pos. dec. № 5008907/33 (059304) from 07/03/91.

7. Dorofeyev V. S., Pushkar N. V. (2018). Deformacii betona zhelezobetonnyh konstrukcij gidrotehnicheskih sooruzhenij pri ciklicheskih vozdejstvijah. [The deformations of concrete of reinforced concrete constructions of hydrotechnical structures under cyclic exposure]. New technologies in construction. Kiev, Issue 3, pp. 35-40.

8. Dorofeyev V. S., Pushkar N. V. and Brednev A. M. (2019). Deformacii betona na beregah tehnologicheskih treshhin pri znakoperemennom vozdejstvii sredy jekspluatacii konstrukcij [Concrete deformations on the banks of technological cracks at sign-alternating impact of the structure operation environment]. Current scientific research in the modern world. PereyaslovKhmelnicki, vol. 1(45) 4, 2, pp. 88-94.

9. Dorofeyev V. S., Pushkar N. V. and Zinchenko H. V. (2020). Obrazovanie i razvitie silovyh treshhin $\mathrm{v}$ zhelezobetonnyh izgibaemyh jelementah [Formation and development of force cracks in reinforced concrete bending elements]. Proceedings of the 7th International Conference on Perspectives of world science education. Osaka, pp. 280-286. 
10. Dorofeyev V. S., Zinchenko H. V. (2017). Chisel'ni doslidzhennja, shho harakterizujut' pochatkovu stadiju roboti kompozitiv [Numerical studies characterizing the initial stage of composites]. New technologies in construction. Kiev, Issue 33, pp. 30-35.

11. Dorofeyev V. S., Zinchenko H. V. (2017). Asimptoticheskij analiz naprjazhenno-deformirovannogo sostojanija i polja sploshnosti u vershiny treshhiny normal'nogo otryva zhelezobetonnyh izgibaemyh jelementah [Asymptotic analysis of the stress-strain state and continuity field at the crack tip of the normal separation of reinforced concrete bending elements]. Current scientific research in the modern world. Pereyaslov-Khmelnicki, Issue 12 (32), part 1, pp. 84-91.

12. Dorofeyev V. S., Zinchenko H. V. and Romaniuk V. V. (2017). Doslidzhennja kharakteru rozpodilu naprughy ta peremishhenj bilja vershyny trishhyny $\mathrm{v}$ zalizobetonnykh elementakh [Investigation of the nature of stress distribution and displacements near the crack tip in reinforced concrete elements]. Resource intensive materials, structures, buildings and constructions. Rivne, Issue 34, pp. 129-135.

13. Zinchenko H. V., Dorofeev V. S. (2019). Stressed-deformed condimion and distruction of technologically damaged reinforced concrete structures. Publishing house "Bzltija Publishing". Monografia: Riga, Latvia, pp. 165-184. doi.org/10.30525/978-9934-588-15-0-56.

14. Dorofeyev V. S., Zinchenko H. V. and Tselikova A. G. (2017). Vplyv tekhnologhichnoji poshkodzhenosti materialu na napruzheno-deformovanyj stan zghynaljnykh zalizobetonnykh elementiv [Influence of technological damage of material on the stress-strain state of bending reinforced concrete elements]. Bulletin of Lviv National Agrarian University, Architecture and agricultural construction. Lviv, Issue 18, pp. 75-82.

15. Dorofeyev V. S., Pushkar N. V. (2018). Vlijanie struktury gidrotehnicheskih betonov na razrushenie pri udarnyh vozdejstvijah [The influence of the concrete structure on the destruction under impact]. Current scientific research in the modern world. Pereyaslov-Khmelnicki, Issue 2 (34), part 6, pp. 35-42.

16. Dorofeyev V. S., Pushkar N. V. (2018). Rujnuvannja ghidrotekhnichnykh betoniv pry diji cyklichnykh navantazhenj i vplyviv [Destruction of hydraulic concrete under the action of cyclic loads and influences]. Proceedings of the International Multidisciplinary Conference "Science and technology of the present time: Priority development directions of Ukraine and Poland". Wolomin, Republic of Poland, pp. 94-97.

17. Dorofeyev V. S., Litvinenko V. V., Pushkar N. V. (2019). Tehnologicheskaja povrezhdennost' i ejo vlijanie na prochnost' kontakta starogo i novogo betonov [Technological damage and its influence on the 
contact strength of old and new concrete]. Current scientific research in the modern world. Pereyaslov-Khmelnicki, Issue 4 (48), part 1, pp. 83-88.

18. Dorofeyev V. S., Litvinenko V. V., Pushkar N. V. (2020). Prochnostnye i deformativnye harakteristiki gidrotehnicheskih betonov sbornomonolitnyh konstrukcij [Strength and deformation characteristics of concretes of composite structures]. Scientific achievements of Modern Society. Liverpool, pp. 442-451.

19. Dorofeyev V. S., Pushkar N. V. (2020). Svjaz' tehnologicheskoj povrezhdennosti betona s prochnost'ju rekonstruiruemyh portovyh sooruzhenij [Relation of technological damage to concrete with the strength of reconstructed port facilities]. Current scientific research in the modern world. Pereyaslov-Khmelnicki, Issue 2 (58), part 1, pp. 75-79.

Information about the authors: Dorofeyev V.S., Professor, D.Sc.,

Professor at the Department of Civil Engineering and Architecture, Odessa National Maritime University 34, Mechnikov str., Odessa, 65029, Ukraine ORCID ID: orcid.org/0000-0002-2412-4134

Myronenko I. M., Associate Professor, $\mathrm{PhD}$, Associate Professor at the Department of Civil Engineering and Architecture, Odessa National Maritime University 34, Mechnikov str., Odessa, 65029, Ukraine ORCID ID: orcid.org/0000-0002-5322-9859

\author{
Pushkar N. V., \\ Associate Professor, $\mathrm{PhD}$, \\ Professor at the Department \\ of Reinforced Concrete Structures \\ and Transport Facilities, \\ Odessa State Academy of Building and Architecture \\ 4, Didrihsona str., Odessa, 65029, Ukraine \\ ORCID ID: orcid.org/0000-0002-4243-7353
}

